\title{
Lawrence Revard
}

\section{Incantations to the Summer Trees in Missouri}

1.

If they don't scream, they explode.

Their swelled brains

bust up horizons in my county.

Sublime hell.

It is a long movie! A montage

of a million arms!

A silence of punctured ear drums.

The folds of gloom.

The forests disgorge a local's tale

of vanishings.

A mulberry night. You can't sleep.

Green beetles

take quick walks on your eyelids.

2.

They burst cyst upon cyst of earth.

Their mesh greaves

handle the air like a barbaric weapon.

Observe silence

like invincible plums. Osage oranges,

such horror-eggs,

are festering without an audience.

Molasses gargoyles,

you might exclaim. Articulate blobs.

Our balcony, suspense,

now that the hour is late. I lean out

to whiff the sweet rot.

Flesh not of my flesh, and blood of light. 